\title{
Pengaruh Harga Emas terhadap Indeks Harga Saham Gabungan dengan Inflasi Sebagai Variabel Moderating
}

\author{
Meliza Putriyanti Zifi' ${ }^{1}$, Tobi Arfan ${ }^{2}$ \\ Politeknik Caltex Riau \\ meliza@pcr.ac.id
}

\begin{abstract}
This study is to see whether the price of gold has an effect on the stock price index with inflation as a moderating variabel. The data used time series because the data of study was used sustainably from 2016 -2018. The data method uses a path analysis. The results of this study will show the effect of price on the composite price index of $0.57 \%$ and there is an effect of price on the composite stock price index with inflation as a moderate variabel of $53.1 \%$. This shows that the existence of the inflation variabel will be able to increase the influence of the gold price variabel on the IHSG.
\end{abstract}

Keywords: Gold Price; Composite Stock Price Index; Inflation

\begin{abstract}
ABSTRAK
Penelitian ini untuk mengetahui apakah harga emas berpengaruh terhadapindeks harga saham gabungan dengan inflasi dengan variabel moderating. Data yang digunakan adalah time series karena data penelitian yang digunakan berkelanjutan yaitu dari tahun 2016 - 2018. Metode penelitian menggunakan analisis jalur. Hasil penelitian ini akan menunjukkan terdapat pengaruh harga emas terhadap indeks harga sahamgabungan sebesar $0.57 \%$ dan terdapat pengaruh harga emas terhadap indeks harga saham gabungan dengan inflasi sebagai variabel moderating sebesar $53.1 \%$. Hal ini menunjukkan bahwa keberadaan variabel inflasi akan dapat meningkatkan pengaruh variabel harga emas terhadap IHSG.
\end{abstract}

Kata Kunci: Harga Emas; Indeks Harga Saham Gabungan, Inflasi

\section{PENDAHULUAN}

Saat ini dapat dikatakan saham adalah produk investasi popular seiiring dengan semakin meningkatnya kesadaran masyarakat dalam menyimpan uang di tabungan tidak meningkatkan nilai tambah lebih. Hal ini menjadi pemicu adanya perubahan gaya hidup dalam pengelolaan keuangan pribadi dari "Saving Society" menjadi "Investment Society". Investasi adalah pengelolaan asset untuk dapat memberikan hasil di masa mendatang. Salah satu alasan masyarakat perlu untuk 
berinvestasi adalah inflasi. Inflasi adalah suatu keadaan meningkatnya harga secara terus menerus (continue) atau keadaan menurunnya nilai uang secara terus menerus.

Keadaan tersebut mendorong minat investor untuk berinvestasi di pasar modal. Salah satu indeks yang sering diperhatikan oleh para investor adalah Indek Harga Saham Gabungan (IHSG). IHSG adalah indeks yang mengukur kinerja harga semua saham yang tercatat di Papan Utama dan Papan Pengembangan Bursa Efek Indonesia. Menurut (Tesa, 2012), keadaan yang lesu ditunjukkan dengan indeks harga saham yang mengalami penurunan sedangkan keadaan stabil ditunjukkan dengan indeks harga saham yang tetap.

Salah satu yang dapat mempengaruhi pergerakan IHSG adalah harga emas. Penelitian (Gaur \& Bansal, 2010) menunjukkan bahwa terdapat pengaruh negatif antara harga emas dan harga saham. Hal tersebut berarti jika harga emas naik maka harga saham akan turun. Naiknya harga emas menyebabkan investor mengurangi investasi saham dan mengakibatkan harga saham turun. Hali ini dikarenakan emas dianggap safe haven. Safe haven adalah aset yang diharapkan nilainya meningkat atau tetap walaupun pasar dalam keadaan tidak stabil. Penelitian lain (Karnila, 2017) menunjukkan bahwa harga emas memiliki tingkat signifikansi sebesar 0,0000 lebih kecil daripada 5\% dan koefisien regresi 1,471983 yang menunjukkan hubungan positif. Berdasarkan hasil tersebut maka harga emas memiliki pengaruh positif signifikan terhadap Indeks Harga Saham Gabungan (IHSG). Penelitian serupa oleh (Reny WA \& Yudinanto, 2018) menunjukkan bahwa harga emas memiliki pengaruh positif signifikan terhadap Indeks Harga Saham Gabungan (IHSG).

Pada peneliltian ini perumusan masalahnya adalah apakah harga emas berpengaruh terhadap indekss harga saham gabungan dan apakah harga emas berpengaruh terhadap indeks harga saham gabungan dengan inflasi sebagai variabel moderating. Dan tujuan dalam penelitian ini adalah untuk mengetahui pengaruh harga emas terhadap indeks harga saham gabungan dan untuk mengetahui pengaruh harga emas terhadapindeks harga saham gabungan dengan inflasi sebagai variabel moderating. Sedangkan kontribusi penelitian ini adalah dapat dijadikan informasi investasi bagi para investor.

\section{KERANGKA TEORITIS}

Menurut (Hartono, 2013) portofolio adalah kumpulan aktiva keuangan dalam suatu unit yang dipegang atau dibuat oleh seseorang investor, perusahaan investasi, atau institusi keuangan. Teori portofolio berkaitan dengan estimasi investor terhadap ekspektasi risiko dan return yang diukur secara statistikuntuk membuat portofolio investasi. Dalam teori portofolio, pengurangan resiko dapat dilakukan dengan menambah jumlah jenis aset kedalam portofolio.

Menurut (Hartono, 2013) Indeks Harga Saham Gabungan (IHSG) adalah angka indeks harga saham yang sudah disusun dan dihitung dengan menghasilkan trend, dimana angka indeks adalah angka yang diolah sedemikian rupa sehingga dapat digunakan untuk membandingkan kejadian yang dapat berupa perubahan 
harga saham dari waktu ke waktu. Emas adalah jenis logam mulia yang sangat diminati untukinvestasi maupun digunakan dalam keseharian. Emas sering disebut sebagai safe haven, yaitu ketika perekonomian global tidak menentu atau ada gejolak geopolitik,emas mempunyai tingkat risiko rendah,. Emas dijadikan safe haven karena ketersediannya langka, banyak diminati, dan sangat berharga secara intrinsik.Menurut (Marsis, 2013) dalam bukunya membahas keterkaitan harga emas dan inflasi. Harga emas biasanya juga berbanding searah dengan inflasi. Semakin tinggi inflasi, semakin tinggi pula kenaikan harga emas.

Inflasi merupakan kenaikan harga secara terus menerus dan kenaikan harga yang terjadi pada seluruh kelompok barang dan jasa (Pohan, 2008). Inflasi akan mempengaruhi harga saham karena investor bereaksi lebih cepat. Ketika perubahan faktor makro ekonomi terjadi, investor akan mengkalkulasi dampaknya baik yang positif maupun negative terhadap kinerja perusahaan beberapa tahun kedepan, kemudian mengambil keputusan membeli atau menjual saham yang bersangkutan. Berdasarkan landasan teori di atas, maka hipotesis padapenelitian ini adalah sebagai berikut:

H1 : Harga emas memiliki pengaruh terhadap indeks harga saham gabungan.

H2 : Harga emas memiliki pengaruh terhadap indeks harga saham gabungan dengan inflasi sebagai variabel moderating.

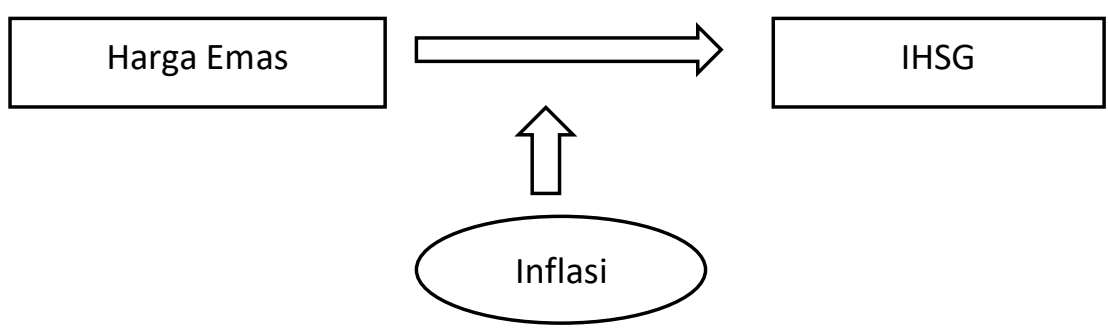

Gambar 1. Kerangka Penelitian

\section{METODE RISET}

Data yang digunakan adalah time series karena data yang digunakan berkelanjutan yaitu dari tahun 2016 - 2018. Metode analisis ini adalah dilakukan uji asumsi klasik.Uji asumsi klasik yang akan dilakukan antara lain uji normalitas, multikolinearitas, heteroskedasitas, dan uji autokorelasi. Selain uji asumsi klasik, pengujian pada hipotesis dilakukan uji t. Uji t dilakukan untuk mengetahui besarnya pengaruh variabel independent secara terpisah terhadap variabel dependen.Metode analisis regresi yang digunakan yaitu analisis regresi moderasi (moderating regression analysis). Moderating Regression Analysis (MRA)adalah Analisis ini digunakan untuk melihat apakah variabel pemoderasi $(\mathrm{Xm})$ mempengaruhi 
pengaruh antara variabel $X$ yaitu suatu variabel yang menekan ataumenerangkan variabel lainnya. Pengaruh variabel harga emas terhadap indeks harga saham gabungan, dan menguji apakah variabel inflasi mempengaruhi harga emas terhadap indeks harga saham gabungan. Moderating Regression Analysis dinyatakan dalam bentuk persamaan sebagai berikut:

$\mathrm{Y}=\alpha+\beta 1 \mathrm{X}+\beta 2 \mathrm{Z}+\beta 3 \mathrm{X}^{*} \mathrm{Z}+\varepsilon$

Keterangan:

$\mathrm{X}=$ harga emas

$\mathrm{Y}=$ indeks harga saham gabunganZ = inflasi

\section{ANALISIS DATA DAN PEMBAHASAN}

\section{Uji Normalitas}

Uji normalitas berguna untuk menguji apakah dalam model regresi, variabel dependen dan variabel independen memiliki distribusi normal atau tidak. Uji normalitas pada penelitian ini menggunakan distribusi pada grafik $P-P$ Plot. Berikut hasil uji normalitas menggunakan $P$-P Plot menggunakan bantuan aplikasi SPSS:

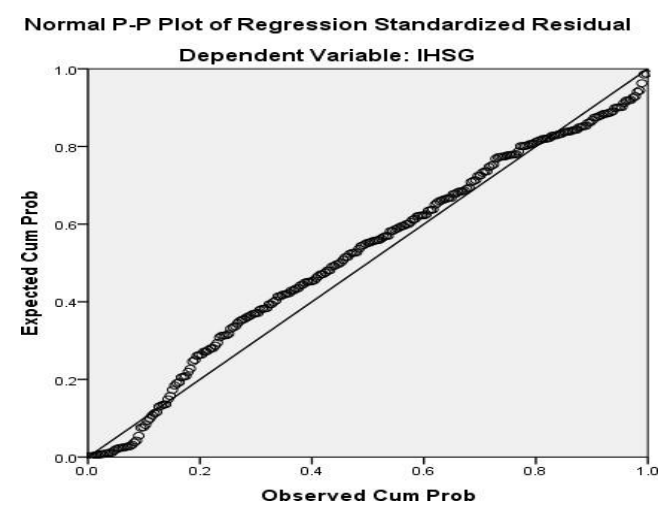

Sumber : Data Olahan SPSS

Dari grafik dapat disimpulkan yaitu data menyebar dan mengikuti arah garis diagonal pada grafik histogram, dan menunjukkan data distribusi normal. sehingga model regresi memenuhi asumsi normalitas.

\section{Uji Multikolinieritas}

Uji multikolinieritas adalah pengujian model regresi apakah ditemukan hubungan korelasi antar variabel independen. Jika nilai Tolerance $>0.10$ dan nilai VIF $<10$. Maka data data bebas dari gejalamultikolinierias.

\section{Uji Heteroskedastisitas}

Uji heteroskedastisitas bertujuan untuk menguji dalam model regresi terjadi ketidaksamaan varians dari residual satu pengamatan ke pengamatan yang lain. Cara untuk mengetahui terjadi heteroskedastisitas atau tidak yaitu dengan melihat grafik Scatterplot antara nilai prediksi variabel dependen yanitu ZPRED dengan 
residualnya SRESID. Tidak terjadi heteroskedastisitas yaitu apabila tidak ada pola yang jelas, serta titik-titik menyebar di atas dan bawah angka 0 pada sumbu Y.

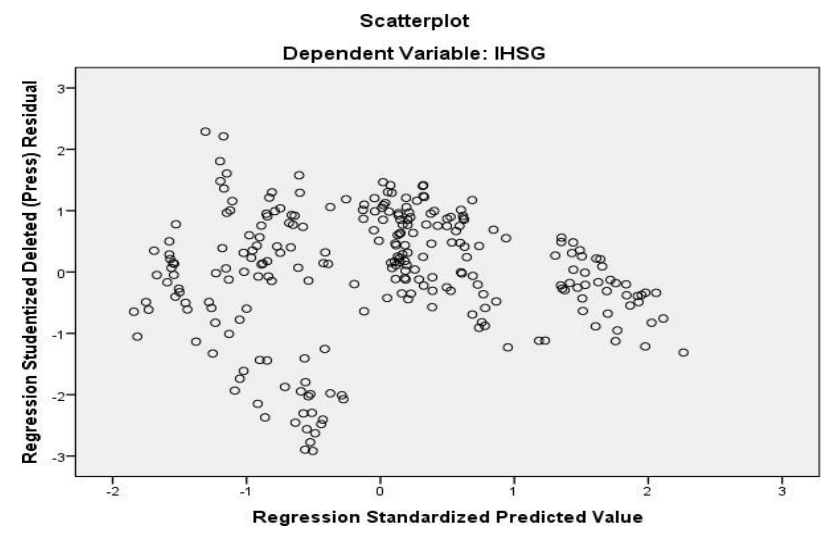

\section{Gambar 3 . Grafik Scatterplot}

Sumber : Data Olahan SPSS

\section{Uji Statistik t}

Uji t bertujuan untuk melihat secara langsung pengaruh variabel dependen dengan beberapa variabel independen. Untuk menjawab hipotesis yang diajukan, maka digunakan uji t. Berikut hasil dari uji t :

\section{Tabel 1. Hasil Uji t}

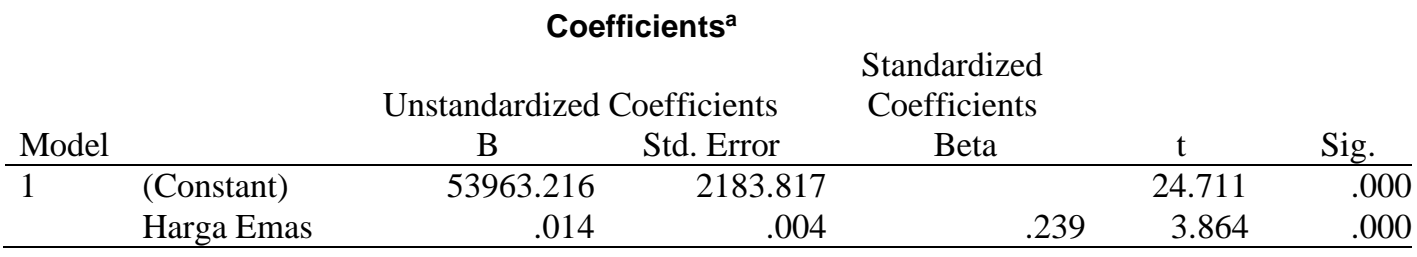

Sumber : Data Olahan SPSS

Berdasarkan tabel di atas dapat dilihat bahwa Harga Emas memiliki nilai t hitung sebesar 3.864 dan nilai signifikansi 0.000 lebih kecil dari a (0.05), maka Ha diterima dan Ho ditolak. Dan dapat disimpulkan bahwa terdapat pengaruh antara Harga Emas terhadap IHSG.

Hipotesis 1: Terdapat pengaruh harga emas terhadap Indeks Harga Saham Gabungan (IHSG).

Berdasarkan hasil analisis output SPSS, maka dapat dilihat dalam gambar berikut: 
Tabel 2.Tabel Anova

ANOVA $^{\mathrm{a}}$

\begin{tabular}{|c|c|c|c|c|c|c|}
\hline & Sum of squares & $\mathrm{df}$ & Mean square & $\mathrm{F}$ & Sig. \\
\hline \multirow{3}{*}{$\frac{\text { Mode }}{\mathrm{a}}$} & regression & $72.243 .541,58$ & 1 & & 14,929 & $0,000^{\mathrm{b}}$ \\
\hline & Residual & 1.195 .292 .743 & 247 & $72.243 .541,58$ & & \\
\hline & total & 1.267 .536 .285 & 248 & 4.839 .241 .876 & & \\
\hline
\end{tabular}

a. Dependent variabel : IHSG

b. Predictors: (Constant), Harga Emas

\section{Gambar 4. Tabel Anova}

Hipotesis 2: Harga emas memiliki pengaruh terhadap indeks harga saham gabungan dengan inflasi sebagai variabel moderating.

Berdasarkan hasil analisis output SPSS, maka dapat dilihat dalam tabel berikut:

Tabel 3. Model Summary Hipotesis 2

\begin{tabular}{|c|c|c|c|c|c|c|c|c|c|}
\hline \multicolumn{10}{|c|}{ Model Summary } \\
\hline & & & & & \multicolumn{5}{|c|}{ Change Statistics } \\
\hline Model & $\mathrm{R}$ & $\begin{array}{l}\mathrm{R} \\
\text { Square }\end{array}$ & $\begin{array}{l}\text { Adjusted } \\
\text { R Square }\end{array}$ & $\begin{array}{l}\text { Std. Error of the } \\
\text { Estimate }\end{array}$ & $\begin{array}{l}\mathrm{R} \\
\text { square } \\
\text { Change }\end{array}$ & F Change & df1 & df 2 & $\begin{array}{l}\text { Sig. F } \\
\text { Change }\end{array}$ \\
\hline 1 & $0,239^{\mathrm{a}}$ & 0,057 & 0,053 & 219.982 .769 & 0,057 & 14.929 & 1 & 247 & 0,000 \\
\hline
\end{tabular}

a. Predictors: (Constant), Harga Emas

b. Dependent Variabel: IHSG

\begin{tabular}{|c|c|c|c|c|c|c|c|c|c|c|}
\hline \multirow[b]{3}{*}{ Model } & \multicolumn{10}{|c|}{ Model Summary } \\
\hline & & & & & & & Chang & Statist & & \\
\hline & $\mathrm{R}$ & $\begin{array}{l}\mathrm{R} \\
\text { Square }\end{array}$ & $\begin{array}{l}\text { Adjusted } \\
\mathrm{R} \\
\text { Square } \\
\end{array}$ & $\begin{array}{l}\text { Std. Error of } \\
\text { the Estimate }\end{array}$ & $\begin{array}{l}\mathrm{R} \\
\text { square } \\
\text { Change } \\
\end{array}$ & $\begin{array}{l}\mathrm{F} \\
\text { Change }\end{array}$ & df1 & df2 & $\begin{array}{l}\text { Sig. F } \\
\text { Change }\end{array}$ & $\begin{array}{l}\text { Durbin } \\
\text { Watson }\end{array}$ \\
\hline 1 & $0,729^{\mathrm{a}}$ & 0,531 & 0,525 & 155.796 .925 & 0,531 & 92,402 & 3 & 245 & 0,000 & 0,138 \\
\hline
\end{tabular}

Berdasarkan tabel di atas, maka dapat dilihat nilai $R$ Square sebesar 0,057 sehingga dapat dikatakan bahwa variabel harga emas berpengaruh terhadap variabel IHSG sebesar $0,57 \%$. Oleh karena itu, hipotesis diterima.

\section{KESIMPULAN DAN SARAN}

Berdasarkan hasil dan pembahasan di atas, maka kesimpulan penelitian ini adalah terdapat pengaruh harga emas terhadap Indeks Harga Saham Gabungan (IHSG) dengan nilai signifikansi 0.000 lebih kecil dari 0.05. Nilai R Square sebesar 0,057 sehingga dapat dikatakan bahwa variabel harga emas berpengaruh terhadap 
variabel IHSG sebesar $0,57 \%$. Terdapat pengaruh harga emas terhadap Indeks Harga Saham Gabungan (IHSG) dengan inflasi sebagai variabel moderating dengan nilai signifikansi 0.000 lebih kecil dari 0.05 . Nilai $R$ Square sebesar 0,531 atau $53,1 \%$ sehingga dapat dikatakan bahwa keberadaan variabel inflasi (sebagai variabel moderasi) akan dapat memperkuat atau meningkatkan pengaruh variabel harga emas terhadap IHSG.

Saran yang dapat digunakan sebagai bahan pertimbangan pengambilan keputusan investor adalah menambahkan beberapa variabel lain yang terkait dengan Indeks Harga Saham Gabungan (IHSG) karena data dapat berfluktuatif sesuai dengan kondisi perekonomian.

\section{DAFTAR PUSTAKA}

Bayu. (2011, Agustus 18). Emas Sebagai Pelindung. Retrieved from Seputar Forex: Pergerakan nilai indeks akan menunjukkan perubahan situasi pasar yang terjadi. Pasar yang sedang positif atau terjadi transaksi yang aktif, ditunjukkan dengan indeks harga saham yang mengalami kenaikan. Keadaan stabil ditunjukkan dengan indeks harga saham

Chabachib, H. M., \& Witjaksono, A. A. (2011). Analisis Pengaruh Fundamental Makro dan Indeks Harga Global terhadap IHSG. Karisma, Vol.5, No.2, 6372.

Gaur, A., \& Bansal, M. (2010). A Comparative Study of Gold Price Movements in Indian and Global Markets. Indian Journal of Finance Vol. 4, No.2, 32-37. Hartono, J. (2013).

Teori dan Praktik Portofolio. Yogyakarta: Salemba Empat.

Karnila, A. (2017). Analisis Pengaruh Suku Bunga SBI, Nilai Kurs, Harga Emas Dunia, Indeks Dow Jones, dan Indeks Hang Seng Terhadap IHSG. Skripsi: Fakultas Ekonomi dan Bisnis UIN Syarif Hidayatullah Jakarta.

Li, C., Guo, L., \& Hu, Y. (2010). A new method combining HOG and Kalman filter for video-based human detection and tracking. 3rd International Congress on Image and Signal Processing (CISP). Yantai: IEEE.

Marsis, A. S. (2013). Rahasia terbesar Investasi. Yogyakarta: Second Hope. Martin. (2014, Mei 25). Apa Itu safe Haven? Retrieved from Seputar Forex: https://www.seputarforex.com/artikel/apa-itu-safe-haven-179168-31

Nurwani, N. (2016). Analisis Pengaruh Inflasi, Nilai Tukar Rupiah, dan Suku

Bunga SBI Terhadap Pergerakan Indeks Harga Saham Gabungan Di Bursa Efek Indonesia. JUrnal Ekonomikawan.

Pohan, A. (2008). Potret kebijakan Moneter Indonesia. Jakarta: PT Raja grafindo. Reny WA, A., \& Yudinanto, Y. (2018). Analisis Pengaruh Suku Bunga SBI, 
Jurnal Akuntansi Berkelanjutan Indonesia - Vol. 4, No. 2, Mei 2021 - Zifi \& Afan

Nilai Kurs, Harga Emas Dunia, Indeks Dow Jones,. Jurnal Ekonomi Universitas Borobudur.

Tani, Y., \& Hotta, K. (2014). Robust Human Detection to Pose and Occlusion Using Bag-of-Words. 22nd International Conference on Pattern Recognition (ICPR) (pp. 4376 - 4381). Stockholm: IEEE.

Tesa, S. (2012). Pengaruh Suku Bunga Internasional (LIBOR), Nilai Tukar Rupiah/US\$ dan Inflasi Terhadap Indeks Harga Saham Gabungan di Bursa Efek Indonesia Tahun 2000-2010. Economic Development Analysis Journal, VOl.1, No.1, 1-13. 